Received: 23-01-2018. Accepted: 19-11-2018. Published: 26-12-2018

\title{
Social Capital Existence in Bali's Microfinance: Evidence from Village Credit Institution (LPD)
}

Pera Sundarianingsih ${ }^{1}$, Khusnul Ashar ${ }^{2}$, Adi Saputra ${ }^{3}$

Economics Department, Universitas Brawijaya Malang, Indonesia ${ }^{123}$

\begin{abstract}
Bali has two village governance systems: administrative-village and customary-village. Administrative-village is the extension of government's authority in administrative aspects. Meanwhile, customary-village (pakraman village) denotes traditional institution that has a function to organize krama (residents) based on the awig-awig (customary law). The role of customary-village is fundamental in carrying on the custom and culture of Bali as well as triggering the economical aspect from the society through Village Credit Institution $(L P D)$. This study is intended to describe the existence of social capital over the $L P D$ by employing inductive-qualitative approach. Social capital over the $L P D$ can improve the societies' harmony that have been established in advance. Furthermore, the social capital bonding, bridging and linking can be used continuously in social life.
\end{abstract}

Keywords: Social capital; poverty alleviation; village credit institution

\section{Introduction}

Social capital reflects bonded relations among people that have similar aim to ease their acts (Coleman, 2008). If a social community has the same purpose, social capital will be formed there. Putnam (1995) called social capital is classified to three types that are based on social system, that is social bonding means a strong relationship within the members while, social bridging implies interaction occurs either inside and outside the community and social linking refers to social relations among members or among varioussocial levels. The other experts, Todaro and Smith (2011), argue social capital denotes some productive values inside the norms and social institutions that covers community belief and there is punishment on every fault. Cooperative behavior and experience of collective action in social capital increases the probability of good involvements to reach the common goals later.

A study conducted by Harrison, Montgomery and Bliss (2016) finds out that social capital considered as the main indicator in any resolutions of community developments. This study discovers any resolutions of community developments can be touched through social bonding, social bridging and social linking. Social capital lies on the society is highly important in facilitating people to reach the common goals. Babaei, Ahmad \& Gill (2012) The other study of social bonding, social bridging and social linking effect on community development is measured by the association between family and close friend/colleagues, local community and ethnic group as well as governmental and non-governmental institution. The result of the study shows social bonding, social bridging and social linking have significant effect toward marginal society development. Here, social bonding has the hugest impact rather that social bridging and social linking.

The presence of social capital and social relationship within society are alike and it can be used by people as an indicator of the better access to join financial institutions by erasing the social barriers existed in society. People with limited collateral have tendency to choose illegal financial institutions rather that the formal ones since it is quite difficult to access the formal institutions (Trinugroho, Nugroho et al., 2017). Social community lies in certain society can raise social capital potential that reflected on how people organize their public interest by looking at the values and local wisdom (public interest, custom or tradition, educational institution, dogma and customary institution) (Abdullah, 2013).

Bali has residents of customary-village community called by Krama of Pakraman Village (Masyarakat Desa Adat). In deal with the economy, Bali uses both of natural resources and cultural resources to work on it (Vipriyanti, 2011). Balinese people has strong affiliation with the customsof HinduBali. In addition, Bali owns two types of village governance that walks in unity and harmony: administrative-village asextension of government's authority in administrative aspects and customaryvillage (pakraman village) as community of customary residents of Hindu-Bali which every norms (krama) are regulated by customary rules (awig-awig) (Suartha, 2015). Customary-village has a vital role in the residents' daily life. In general, tradition in Bali teaches people to take care of and do the jobs as well as

1 Pera.sundaria@gmail.com 
the responsibilities as the residents of customary-village also obey the rules of customary-village (awigawig) (Kurniasari, 2007). The Balinese people involvement in economical aspect can be seen on Village Credit Institution (LPD) that have been established.

In 2015 Bali has the fourth lowest poverty rate nationally (BPS Indonesia, 2016. Bali's economydriven drivers are not only based on natural wealth, but also from the world-renowned culture that impacts Bali's foreign exchange and the Balinese economy. LPD is a financial institution of saving and loan by using banking standard that makes LPD looks like real bank at a glance. The different between bank and LPD is on the background as well the purpose. In this case, LPD is generated, organized and reservedfor pakraman village as a local community (Sukandia, 2011).

The existence of social capital as previously described and the social relationships established in the community are important indicators that can be used by society in removing social barriers such as access to entry into wider financial institutions. Developing countries has the social barriers, it many small credit providers programs that are intended for people with limitations in the fulfillment of life as well as expanding businesses such as the development of Small Micro Enterprises (SMEs) (Ashar, 2011). The existence of LPD in Bali was able to revive the wheels of the economy as at the time of the Bali bombing I, where the Balinese economy suffered a setback that could develop faster is Micro Small Business (UKM), where the financing of SMEs is through LPD) (Kurniasari, 2007).

In a nutshell, everyone has social capitals. Some of them have already identified and utilized while the rest of them still face some difficulties to optimize their own social capital. Based on the description above, this present study intends to define how the presence of social capital in the form of Village Credit Institution (LPD) can be used continually and reach expected benefits of the common goals, especially in accordance with the locality of customery villages.

\section{Literature Review}

The first social capital theory comes up because of the published work by Pierre Bourdieu on 1970s (Fine and Lapavitas, 2004 cited by Yustika, 2013). This theory emphasizes the concept of association. It states that people should cooperate each other to reach the established goals and maintain it all the time since any kinds of individual works are harder indeed (Field, 2010).

Loury (1987), cited in Coleman (2008), was a pioneer of social capital that has concern to define the associations among sources within family relationship's and its benefit in socio-cognitive aspects' development of children or teenagers. Those sources are child growth matters lies in and outside the family as well as inside the community. Loury explains the social capitals as something called by norms, social systems and also kin relationships. Woolcock (2001) differs social capital into three types: Social Bounding as values, cultures, tradition and mores or customs, Social Bridging as institution and mechanism as well as Social Linking as relations or systems.

Social bonding is one of the types of social capital that has strong bond characteristic within the society. For instance, most of family have sense of kinship with the other families. This kinship relationship is bringing on the empathy/intimacy. It can also grow the sense of sympathy, duty, trust and interrelationship toward their cultural beliefs. Rule of the game is a regulation or deal within society. It can be formal one that has clear punishment in the form of protocols. Other than that, non-formal punishment can be given in the form of exclusion, disrespected by the people around. It makes people afraid whenever they do not obey the rules and duties. As the effect, social order will arise automatically.

The next is social bridging. Social bridging is connector within the social bond that emerges because of the reaction on various community characteristics. The weaknesses that occurs around the society forces them to make a communal power to erase that weakness. Social bridging can also be seen in the any publics' involvement as citizens and community members. The main point here is to develop the inner potential of society, so they can maximize and reach their own potency such as human resources and natural resources.

Social capital capacity is manifested to those three things (value, institution and mechanism) and it is used to unify numerous backgrounds of ethnic, religion and socio-economical level. Thus, incapability of society to synchronize the values, institutions and mechanisms in the cross-community level can inhibit them in developing their social capital and social integration in general. The ultimate types of social capital are social linking. Social linking can be interpreted as a correlation of several social status exists in the society. For example, the correlation between elite politicians and common people. In this context, the elites are considered as public figures and they are more respected. Nevertheless, both elites and common people are having the similar interest to make a relation. 
Basically, those three types of social capital are working based on the situation. It can deal with the strengths or weaknesses within society. It can also be applied to support or even inhibit the social bonds. One thing that should be underlined is that it really depends on how people interpret it.

\section{Methodology}

The research design employed in this study was inductive-qualitative approach. Understanding social situation in the society through Village Credit Institution (LPD) activityatPekutatan customaryvillage, PekutatanSub-District, Jembrana District, Bali became the main concern here. For the research instruments, the researchers used in-depth interview, documentation and observation to collect the data. The data were collected repeatedly in order to make the most appropriate relation pattern based on the data gathered (Sugiyono, 2012). The key of informants in this study consisted of the Chairperson of the LPD, 2 (two) LPD Customers, the Customary Village Head (Bendesa Desa Adat), the Secretary of the Customary Village (Penyarik Desa Adat).

According to Miles and Huberman (2014), field analysis should be completed interactively and continually until the investigated data were finish and presented its saturation point.This activity was done by having data reduction, data display and conclusion. On the other side, the credibility test (internal validity) utilized triangulation method. The triangulation at credibility test was considered as data examination from various sources, ways and times (Wiersma, 1986).

\section{Result and Discussion}

Balinese people are inseparable with their local wisdom on the daily life and they areholding strong on the custom values and cultures indeed. Balinese people consist of two different villages' territory: HinduBalinese people and Common-Balinese people. The first category is known as krama pakraman village that living in customary-village (desa pakraman) and all the public orders are regulated by the existing customary law (awig-awig) (Raga \&Mudana, 2013). The second category, Common-Balinese people, is including in administrative-village territorythat consist of administratively heterogenous society and they are living in a specific village which has no any races and religion boundaries. In addition, customaryvillage is led by kelianadat while administrative-village is commanded by headman/perbekel.

Both residents are living side by side and completing each other. Customary-village handles every single Hindu-Bali needs and matters while administrative-village takes care of government's tasks and the other general concerns. Living in Bali can be called asmenyamabraya that means living side by side based on the philosophy of karma marga. It is taken from values' system, culture as well as customs to keep the peaceful situation among Balinese people (Pageh, Sugiartha \& Artha, 2013). The diversity in Bali is an undeniable image of harmony, intimacy and peacefulnessduring socialization.

"Karna itulah tadi.. krama (masyarakat) Bali ini, mental kembali... penduduk Bali apapun itu agamanya itu termasuk kualitas 1 itu, baik muslim yang penting dia itu memang asli Bali, beda mentalnya, tetangga saya kan muslim sebagian, karna dari kita ajak tetangga seperti keluarga gitu” (Bendesa Adat, 2017)

"Because of that ... the Balinese (community) manners, mentally returned ... whatever Balinese are, their religion is included in that quality, both Muslims who are important he is indeed Balinese, mentally different, my neighbors are Muslims in part, because of we invite neighbors like that family "(Bendesa Adat, 2017).

Harmony, familiarity as a form of interaction that often occurs in society, especially in neighboring life. The smaller the scope of the relationship increases the stronger the closeness.

Afterwards, customary-village in Bali that known as $\neg$ pakraman village, is a homogenous traditional institution based on its geographical aspect on Hindu-Bali community. The intense social interaction on the daily life raises unity and teamwork as a replication of the good cooperation. Pakramanvillage has both written and unwritten rules so it will be automatically respected by the people especially by krama (residents).

Pakraman village utilizes community instruments and socio-culture (awig-awig, pesangkepan and perarem) in collecting and organizing their finance. As the benefit, it helps people to handle, develop and maintain their own financial capacity in Village Credit Institution (LPD) that builtright in the middle of community (karma pakraman village).

Village Credit Institution(LPD) is a financial institution belongs to the village that explicitlyhas different establishment with common financial institution or bank. Background and purpose of LPDare clearly inspired by the daily life of Balinese people. The orientation of LPD's establishment shows the solid 
characteristic of the institution such as it is organized by and for people inside the community, pakraman village. The presence of LPD can support the growth ofmicro-industries in the village (Kurniasari, 2007). Even though LPD is made for internal people purpose (Hindu-Bali), now it becomes more flexible by opening the opportunity for non-community of Hindu-Balinese people. It also happens on LPDof Pakutatan customary-village that basically has heterogenous race and religion. Hence, to interpret the local wisdom of menyamabraya, LPD of Pakutatan customary-village tries to engage non-community people to get the equal service.

Micro system aspect of LPD and society, as well as community people and non-community people are spreadablethings within the territory. The sustainability of LPD is firmly affected by people trust, so they are motivated to keep using LPD's services.

“Gini, kalau ya mungkin karna temen ya... gampang disana... pertelfon aja kita ndak usah kekantornya dateng. Itu mudahnya... apa karna mungkin karna kita temen... sama bosnya juga tau, kenal, trus pegawainya juga sering sini mungut (pengambilan tabungan) ni dah kayak tabungan.." (Nasabah LPD $\mathrm{Ke}-1)$

"If it is possible, it's because of friends... it's easy there ... we just don't have to call it for office. That is easy ... because maybe because we are friends ... the boss also knows, knows, then the employee is also often here (taking savings) is like savings..." (1st LPD Customer, 2017)

The same was explained by informants of other LPD service users, namely the 2nd LPD Customer, namely as a form of contagious action in the form of mutual trust given by the LPD to the community, so that the community also always uses LPD as a financial service institution.

"Iya... kalau udah gini, apa namanya... cepet gitulho... kalau udah dipercaya gitu cepet dah ndak nyampe itu 3 udah hari, kan lumayan...” (Nasabah LPD ke-2)

"Yeah ... if it's already been done, what's the name ... hurry up gitulho ... if it's been trusted it's so fast it's not available, it's already 3 days, it's not bad ..." (2nd LPD customer, 2017)

The applied norm binds people to obey the existing rules in the society. It is indicated by people's discipline in managing their finance. The residents who obey custom rules (awig-awig) binds themto obey it. Custom/traditional punishment practiced in LPD is more feared than formal punishment such as foreclosure/auction.

"Yang paling menakutkan bagi kami masyarakat adat..tidak mendapat pelayanan adat. Misalnya, kalau orang hindu itu ada upacara kawin..dia kan butuh minta saksi seperti di KUA itu...itu bisa ditolak...misalnya ada upacara kematian...dia itu minta penyelesaian ke kita di desa kuburan itu, itu ndak dilayani seandainya ada yang membandel..." (Bendesa Adat, 2017)

"The most frightening thing for us is indigenous people ... they don't get traditional services. For example, if the Hindu is a marriage ceremony... he needs to ask for a witness like in the KUA... it can be rejected... for example there is a death ceremony... he is asking for a settlement to us in the cemetery village, it is not served if there is something stubborn... "(Bendesa Adat, 2016)

"Iya, karna dia takut dengan awig-awig sebenarnya... Kalau muslim itu juga punya awig kayak kita itu... saya dauh pangkung (nama daerah) itu di masjid taqwa saya tau itu... ndak berani juga dia takut dengan awignya... punya dia awig itu, kayak peturuan bangunan masjid... makanya kita tu menyamabraya dari dulu tu... hampir sama itu.." (Penyarik Desa Adat, 2017)

"Yes, because he is afraid of awig-awig actually... If that Muslim also has awig like us... I am dauh pangkung (regional name) at the mosque taqwa I know that... I don't dare he is afraid of his... have he is awig, like a mosque building... so we make it a long time ago... almost the same..."(Penyarik Adat, 2017)

Through loan distribution by LPD, Hindu-Balinese people help maintaining the harmony among religious people, indirectly. The local wisdom of menyamabraya can be seen from involvement of HinduBalinese people as guarantors for non-community people to get the access of LPD'sloan. 
"Ada anggota umat hindu yang sebagai penjamin. Misalnya, saya punya temen, temen saya di muslim...temen baik niki..dia ada kepentingan dana ini..ini...itu.. secara aturan dia kan tidak dalam organisasi ini...saya menjamin bahwa saya, temen saya ini tidak akan melarikan diri" (Bendesa Adat, 2017)

"There are members of the Hindu community who are guarantor. For example, I have a friend, my friend in Muslim... good friend, he has the interest of this fund... this... that... by the rules he is not in this organization... I guarantee that I, my friend this will not run away " (Bendesa Adat, 2017)

Social bonding displays interrelationship that promotes a deal or rule of the game. It is applied in the menyamabrayarelation at Pekutatanvillage which non-community people can get the access of LPD's loan only if they have guarantor from the residents/community of customkrama.

"Iya kalau macet, penjamin inilah yang bertanggung jawab gitu, haahhahahaa, karna dia memberitahukan itu .."(Penyarik Desa Adat, 2017)

"Yes, if it is stuck, this guarantor is responsible, haahhahahaa, because he told me that ..." (Penyarik Desa Adat, 2017)

LPD of Pekutatan village is located within the heterogenous society so the customers are coming from the varied social backgrounds. By keeping up the value of togetherness and upholding the tolerance in society, LPD is also channeling funds through loans to the non-community people. In addition, LPDs prioritize clients with urgent credit needs such as funds for ceremonial needs, as well as the need for medical expenses, where interest rate loans are lighter than credit needs in other sectors.

Kinship-relation as well as solid tolerance manner cultivates a harmony in society (menyamabraya). It is proved by manifestation of community involvement in social system relationship such as they give recommendation to the non-krama Pakraman village customers: close friends, public figures or even the customers from karma Pakraman village it self. A good one's reputation leads into a trusted social system that boosts the mutual trust and enhances the system in social relationship. The importance of harmony, intimacy and tolerance has a huge impact in this positive development. It makes all the individual needs are overcame by harmony and intimacy in the daily life (menyamabra).

As a local community that live side by side in the same place, Pekutatan village applies and maintains harmony in the society. Moreover, the solidness of local wisdom always exists in the daily life and it makes people easier to have financial deals. Research conducted Widiyanti, Pudjihardjo, Saputra (2018), that Women is a very vulnerable in resource ownership. Therefore, women's empowerment can be done through micro financing. Women often have difficulty in obtaining access to formal financial institutions, through women's financial cooperative institutions which are viewed on the basis of social capital elements of trust, norms and networks having a positive impact on poverty alleviation. On every kind of social capital that is living in society, it belongs to the public and it is arranged well by the organization horizontally. Hence, the active social capital will last forever in daily life.

The liveliness of institutions has a strong bond with the solid managements inside and the good social relations outside. Village Credit Institution (LPD) of Pekutatan customary-village still alive although there is a lot of competitors that offer better deals than LPD.This phenomenon occurs because of the great cooperation among managements as well as residents' community in keeping LPD exist.

The social bonds among managements and residents' communities occurs because there is a weak point occur within the society itself. It makes the appropriate utilization of the resources fundamental to cover that weaknesses. LPD will not be able to survive without a good work of managements as well as people outside. If LPD has bad reputation, surely there will be no any people come to deposit their money. In other words, the social bonds develop within society can treat the weaknesses.

Arsyad (2005) in his research on the performance of microfinance institutions (LPD), that the sustainability of LPD is also influenced by the support of formal institutions such as government policies that legalize the existence of LPD, while informal institutions are through the existence of customery villages LPD. Collaboration between LPD and government to boost human resources can be seen in the form of several trainings such as cashier, administrators, staffs and board members. Beside trainings, LPD has a duty in reporting the monthly financial statements to the local government through LPD Development and Training Institution (LPLPD) that technically has a responsibility to empower the LPD. Every LPD's report toward LPLPD, it must be signed by bendesa adat (elected head of the customary-village) and perbekel. 
"Kalau dulu si Provinsi yang melaksanakan..kabupaten gitu..tapi sekarang udah lain..lain sekarang tetep nanti provinsi yang menyelenggarakan tapi tetep kerjasama dengan BKS, kalau sekarang perda yang baru ini yang keluar ini kayaknya provinsi yang melaksanakan atau ga kabupaten itu, karena ada dana 5 persen itu yang kita setor dari keuntung bersih setiap tahun sebesar 5 persen itu kita setor kesana itu dah nanti dibagi lagi dipusat, untuk pelatihan sekian untuk kegiatan ini sekian gitu..ini sekian.. gitu dah..kalau dulu pemerintah yang melaksanakan sebelum LPD bagus, artinya berkembang, kita mengawali berdirinya, memang si kita baca dengan peraturan daerahnya ada anggaran dari pemerintah untuk dana pelatihan.." (Kepala LPD, 2017)

"In the past the Province that implemented the regency was like that... but now it's already different... other provinces are still holding on but still working with BKS, if now this new regulation that comes out seems like the province that runs or not, because there is a 5 percent fund that we deposit from the net profit every year of 5 percent, we deposit it where it will be further divided in the center, so for this activity the training is so... here it is... that's the way... before the government implement before the LPD is good, meaning that it develops, we start the establishment, indeed we read with the regional regulations there is a government budget for training funds... "(Head of LPD, 2017)

There is LPD's earning allowance that specifically allocated as technical development funds after the profit is being reported to the local government. This developmental funds' allowance is one of the ways in improving human resources through various training programs held by the local government to develop the LPD. Profit sharing's components are arranged at Local Regulation no. 4/2003 of LPD's net profit report.

Another good deed given by LPD to the customary-village is by giving the earning allowance for $5 \%$ as social funds and $20 \%$ as developmental funds.

“Kalau dibilang simpan pinjam, iya... pelaksanaannya memang seperti itu.. tetapi sebenarnya ini dia untuk menopang kehidupan kita, melaksanakan ritual agama, kemasyarakatan juga, kan awalnya kita kan keluar dulu dana apa namanya itu simpanan wajib, kalau di bali namanya pecintrem"(Bendesa Adat, 2017)

"If you say savings and loans, yes ... the implementation is indeed like that ... but actually this is to support our lives, carry out religious rituals, community as well, right first we will go out first, what is the obligatory savings, if in Pecintrem"(Bendesa Adat, 2017)

The local wisdom that maintained by Balinese people generally and pakraman pekutatan village specifically exists in the perfect harmony at any religious ceremonies. The religious ceremonies are always spending much money. In this case, LPD's role is essential in fulfilling the needs of pakraman village. LPD and pakraman village has strong relationship especially in celebrating the religious ceremonies there.

The social funds given by LPD to the society usually in the form of social-religious supports such as subsidizing manusayadnya (cutting teeth) ritual, giving transportation-funds to the chief of customary council, supporting village sekehe-sekehe: constructing ogoh-ogoh at national Independence Day August 17 th. For the village developmental funds, this is another LPD's contribution to help customary-village and it is fully organized internally then. The bigger profits LPD's got, the larger contribution that is given to the residents (krama).

Social bridging is kindly presented in a respectable cooperation between LPD's managements and society. It happens since there is a good system as well as solidarity among staffs or managements. The social bonds tied results in no limitation from administrative governance to LPD in administering any kinds of trainings even sometimes the managements left their post to do that. In addition, the other cooperation of LPD and village-governance makes both of them participated actively on every single activity held by LPD such as End Year's Meeting or even performance reports that should be delivered to the district.

"Iya..kan hubungan kita silang seling dik ya.. antara kita di LPD dengan pengawas.. pak bendesa.. kepala desa bagus.. kadang-kadang ada itu hubungannya ndak bagus.. kadang-kadang kepala LPD dengan bendesa itu ndak bagus... ada itu.. ketua LPDnya jelek'in bendesanya.. bendesanya jelek'in bendesanya.. ada itu.. padahal disinalah kita tetep.. ya artinya.. tetep koordinasilah.. artinya dengan bendesa.. kepala desa.."(Kepala LPD, 2017)

"We will have interrelated relations in between... we are in the LPD with the supervisor... Bendesa Adat... the village head is good... sometimes there is a connection that is not good ... sometimes the LPD head with 
bendesa adat is not good... there is that... the LPD chairman is bad ... the thing is the bad thing is the thing ... there is it... even though this is where we are still ... yes it means ... keep coordinating ... it means by bendesa... village head... "(Head of LPD, 2017)

The cross relations between LPD and bendesa as the head of pakraman village along with headman as the chief of administrative-village makes them communicate each other's whenever there is an event held. This becomes the power utilization among the whole involved stakeholders. Simply said, either bendesa and headman are the perfect medium to carry the information gathered from the residents and it makes LPDs easier to decide what should they do, for instance in giving credit and things like that.

\section{Social Linking as a Liaison between Society and LPD through Local Meeting (Paruman Desa)}

In constructing policies, societies are contributedenthusiastically to help LPD formulates ideas until evaluation phase of how LPD's work. They also contribute when LPD creates awig-awig or perarem, arranges the internal managements and evaluates credit worthiness. According to LPD's organizational structure, the highest position belongs to ParumanDesa or it is usually called by village meeting that is participated by the residents and public figures. Therefore, every LPD's activity surely accompanied by societies including in formulating policies by having discussion. That activity is known as sangkep (a meeting).

"Kalau pertanggungjawaban setiap tahun..kalau rapatnya itu sering sekali..setiap ada moment itu kita rapat..seperti hari raya..piodalan itu rapat” (Penyarik Desa Adat, 2017)

"If the accountability is every year... if the meeting is often... every moment we will meet... like a holiday... the capital is meeting" (Penyarik Desa Adat, 2017)

Social linking can be interpreted as a broader interrelation of societies. Either strong or weak relationship bonds they will depend on the typical interaction, whether it is exclusive or inclusive. The relation between individual and community in the different social level (vertical situation) is determined by social class where the higher they are, the more fortunate they are (Babaei, Ahmad \& Gill, 2012). The social linking refers to more varied relations at the connections or involvements of all communities and systems.

"Di prarat dah kita bahas itu, disanalah kita di godok..dalam prarat..pertanyaan dimunculkan, saran dimunculukna, artinya seperti kalau kita mengeluarkan unek-uneklah..gimana masukannya lebih menukiklah..tentang LPD itu, masyarakat kan nanti banyak yang mengkritik, saran, ada yang suka banyak, ada yang suka ndak banyak" (Kepala LPD, 2017)

"We have discussed it in prarat, that's where we were teased... in terms of preliminary questions raised, suggestions were raised, meaning that if we issue a statement... how can the input be swooping... about the LPD, many people will criticize it later?, suggestions, there are those who like a lot, some don't like much "(Head of LPD, 2017)

"Setiap RAT (Rapat Akhir Tahun), Tutup Akhir buku..setiap akhir tahun itu, secara simbolis diserahkan dah (SHU 20\%)” (Bendesa Adat, 2017)

"Each RAT (End of Year Meeting), Close End of book... every end of the year, symbolically handed over (SHU 20\%)" (Bendesa Adat, 2017)

"Karna itu sudah merupakan aturan, perda itu yang berbunyi demikian, disaat rapat akhir tahun ya diserahkan... untuk dana pembangunan desa pakraman”(Bendesa Adat, 2017)

"Because it is already a rule, the regional regulation reads like that, when the year-end meeting is handed over... to the development fund of Pakraman village" (Bendesa Adat, 2017)

Budget plan and budget realization are the annual agenda of LPD's masterplan. Firstly, the budget plan is arranged by LPD's managements and it will be delivered at paruman desa that is attended by the public figures: bendesa, Supervisory Board of LPD, headman or kelian banjar in the End Year Meeting (RAT). Next, that activitywill be approved by bendesa as the chief of karma pakraman village and be 
overseen by perbekel. After this evaluation is over, the result will be administered in the RAT that is fulfilled by residents of krama pakraman village from each subdivision village. This whole process is always done by LPD's Pekutatan customary-village once a year.

Other than that, the similar pattern also works in constructing awig-awig by having general discussion based on the existed formal regulation as well as social-economy situation. In other words, the policies made/perarem is still conformingthe constitutional law at National Republic of Indonesiaas one unity that has various tribes, customs, religions and cultures. It makesthe application of awig-awig is still regarding on the social economy condition of both internal communities and entire societies.

\section{Conclusions, suggestions and limitations}

Social capital evolves within society through Village Credit Institution (LPD) of Pekutatan customary-village is indicated by its intermediary function in opening the chance for people to start the business. Then, social bonding as a togetherness principle (menyamabraya) in society is showed by a great social bond among people to help someone that have limitation to access the legal financial institution. Besides, social bonding capital simplifies and prevents a tort while the process of distributing credits. The next is social bridging, LPD as the facilitator fulfills people's needs by giving the earning allowance for $5 \%$ as social funds and $20 \%$ as developmental funds to them. The relationship among society, customary community and LPD is getting stronger because of the active residents' participation on the decisionmaking process that is delivered via paruman desa. It will make krama have low credit-rates when they need money. By having a direct involvement through paruman desa about LPD's management systems, people on different social levels will get closer each other indirectly.

\section{References}

Abdullah, S. (2013). Potensi danKekuatan Modal Sosial dalam Suatu Komunitas. Jurnal Socius, Vol 12.

Ashar, K. (2011). Analisis Terhadap Kesinambungan Lembaga Pembiayaan Pedesaan dalam Mendukung Usaha, Mikro Kecil dan Menengah. Journal of Indonesia Applied Economic , Vol.5, No.1.

Babaei, H., Ahmad, N., \& Gill, S. S. (2012). Bonding, Bridging, and Lingking Social Capital and Psychological Empowerment among Squatter Settlements in Tehran, Iran. Journal of Basic and Applied Scientific Research, Vol. 17 No.1.

Badan Pusat Statistik Indonesia. (2016).

Coleman, J. S. (2008). Dasar-dasar Teori Sosial. Bandung: Nusa Media.

Harrison, J. L., Montgomery, C. A., \& Bliss, J. C. (2016). Beyond the Monolith: The Role of Bonding, Bridging, and Linking Social Capital in the Cycle of Adaptive Capacity. Journal Society \& Natural Resources, Vol 29, No.5.

Kurniasari, T. W. (2007). Lembaga Perkreditan Desa (LPD) dalam Perspektif Hukum:Sebuah Lembaga Keuangan Adat Hindu Penggerak Usaha Sektor Informal di Bali. Jurnal Masyarakat dan Budaya , Vol. 9 No. 1.

Miles, M., Huberman, A., \& Saldana, J. (2014). Qualitative Data Analysis, A methods. USE: Sage Publication.

Nugroho, I. T. (2017). Households, Financial Distress, and Predatory Lending: An Experimental Study. Jurnal Keuangan dan Perbankan, Vol 21. No. 3.

Pageh, I. M., Sugiartha, W., \& Artha, K. S. (2013). Model Integrasi Masyarakat Multietnik Nyama BaliNyama Selam Belajar dari Enclaves Muslim di Bali. Denpasar: Pustaka Larasan.

Putnam, R. (1995). Tuning In, Tuning Out: The Strange Disappearance of Social Capital in America. Journal of Political Science and Politics, Vol. 28, No. 4.

Putra, I. M., \& Apriliani, I. (2010). Modal Sosial dalam Pemberdayaan Desa Pakraman Studi Kasus Pengelolaan LPD Desa Pakraman Batuaji Kawan, Kabupaten Tabanan, Provinsi Bali. Jurnal Kebijakan dan Administrasi Publik, Vol. 12 No. 2.

Raga, G., \& Mudana, I. W. (2013). Modal Sosial dalam Pengintegrasian Masyarakat Multietnis Pada Masyarakat Desa Pakraman Bali. Junal Ilmu Sosial dan Humaniora, Vol. 2 No.2.

Suartha, I. D. (2015). Hukum dan Sanksi Adat Perspektif Pembaharuan Hukum Pidana. Malang: Setara Press.

Sugiyono. (2012). Metode Penelitian Bisnis (Pendekatan Kuantitatif, Kualitatif dan R\&D). Bandung: Alfabeta.

Sukandia, I. N. (2011). Landasan Teoritik Pengaturan LPD. Denpasar: Udayana Press.

Todaro, M. P., \& Smith, S. C. (2011). Pembangunana Ekonomi. Jakarta: Erlangga. 
Trinugroho, I., Nugroho, A. A., Harmadi, Suyono, J., \& Toro, M. J. (2017). Households, Financial Distress, and Predatory Lending: An Experimental Study. Jurnal Keuangan dan Perbankan, Vol. 21 No. 3.

Vipriyanti, N. U. (2011). Modal Sosial danPembangunan Wilayah, Mengkaji Succes story Pembangunan di Bali. Malang: UB Press.

Widiyanti, E., Pudihardjo, \& Saputra, P. M. A. (2018). Tackling Poverty through Women Empowerment: The Role of Social Capital in Indonesian Women's Cooperative. Jurnal Ekonomi dan Studi Pembangunan, Vol. 10 no. 1 .

Wiersma, W. (1986). Research Methods in Education; An Introduction; Forth Edition. Boston, London, Sydney, Toronto: Massachusetts: Allyn and Bacon, Inc. 
Social Capital Existence in Bali's Microfinance... (Sundariangingsih, Ashar, Saputra) 